\title{
Medievalista
}

\section{Martin Codax: a história que a música conta}

Martin Codax: time story told in music

\section{Manuel Pedro Ferreira}

\section{OpenEdition}

\section{Journals}

\section{Edição electrónica}

URL: http://journals.openedition.org/medievalista/1700

DOI: $10.4000 /$ medievalista. 1700

ISSN: 1646-740X

\section{Editora}

Instituto de Estudos Medievais - FCSH-UNL

\section{Refêrencia eletrónica}

Manuel Pedro Ferreira, « Martin Codax: a história que a música conta », Medievalista [Online], 24 | 2018 posto online no dia 16 março 2019, consultado no dia 19 abril 2019. URL : http:// journals.openedition.org/medievalista/1700 ; DOI : 10.4000/medievalista.1700

Este documento foi criado de forma automática no dia 19 Abril 2019

(C) IEM 


\section{Martin Codax: a história que a música conta}

Martin Codax: time story told in music

Manuel Pedro Ferreira

\section{NOTA DO EDITOR}

Data recepção do artigo / Received for publication: 16-05-2018

\section{Introdução: em torno dos géneros da lírica galego- portuguesa}

1 Na lírica medieval galego-portuguesa a música que se conserva é mínima e as novidades têm também escasseado ${ }^{1}$. Sobrevivem melodias em apenas dois pergaminhos, ambos já estudados e divulgados em papel ou gravação. Ultimamente, porém, sobreveio alguma agitação, amplificada por publicações comemorativas do centenário da descoberta e da primeira edição facsimilada (1915) do Pergaminho Vindel.

2 É do conhecimento geral que, em 1984-1986 e 1993-1995, respectivamente, preparei edições tanto deste manuscrito, que contém as cantigas d'amigo de Martin Codax, como do Pergaminho Sharrer, onde se encontram, em estado fragmentário, sete cantigas d'amor de D. Dinis. Por circunstâncias várias, esta última edição só foi publicada em livro dez anos depois da correspondente gravação discográfica² ${ }^{2}$. As edições, acompanhadas por estudos aprofundados, obrigaram-me a formular ou a tomar partido sobre questões que afectam a imagem geral da tradição galego-portuguesa. Isto implica que a respectiva discussão académica, mesmo em âmbito não musicológico, as tem tomado como referência, quer apreciativa, quer criticamente.

3 No primeiro livro, 0 som de Martin Codax, encontra-se uma descrição codicológica detalhada, de primeira mão, do bifólio achado por Pedro Vindel, para além de ampliações 
fotográficas e da primeira reprodução integral do Pergaminho (a quatro cores, na sua face escrita). Apresentam-se ainda uma edição paleográfica, textual e musical, e uma análise comparativa da notação musical; esta é a base da edição crítica seguidamente proposta, que constitui o núcleo do volume, e que dá azo a um exame aturado da relação da música com a poesia, em particular no plano da acentuação. No segundo livro, Cantus coronatus, depois da necessária contextualização, faz-se uma descrição detalhada do Pergaminho Sharrer e das consequências do seu restauro, propõe-se uma edição crítica das melodias e faz-se uma análise quer da relação entre texto e música, quer da relação deste repertório com outros seus contemporâneos; conclui-se que o perfil das melodias dionisinas, neste género "de amor", pouco parece dever à tradição da cantiga "de amigo".

4 Entre as críticas recentes ao meu trabalho, a que julgo mais interessante deve-se a William D. Paden, professor americano especializado na lírica medieval francesa. Essa crítica decorre, em parte, da sua opinião sobre os géneros da poesia galego-portuguesa, desenvolvida num artigo de $2006^{3}$. Nesse texto, inspirado pela constatação de Tavani de que cantiga d'amigo e cantiga d'amor se afiguram o reverso uma da outra ${ }^{4}$, Paden aborda esses géneros como sendo equivalentes e complementares, socialmente solidários, formando um sistema único de diálogo entre amantes ficcionais, no qual a voz feminina da cantiga d'amigo é aquela a quem se dirige o trovador na cantiga d'amor, e o amigo ausente do primeiro género é a voz trovadoresca do segundo. 0 corolário desta visão é o abandono da terminologia trecentista da Arte de Trovar, na qual a designação "cantiga d'amor" seria com vantagem substituída pela expressão "cantiga de senhor", julgada quer mais simétrica relativamente à cantiga d'amigo, quer mais consentânea com a realidade literária revelada pelo uso de palavras-chave.

5 Apesar dos seus atractivos, esta visão, ao assimilar, por um lado, o mundo da donzela ao da senhora a quem se presta vassalagem de amor, e por outro, o cancioneiro do jogral ao do trovador, ignora a dualidade sociológica representada em cada género e a diversidade das suas raízes; esbate a diferenciação, para muitos crucial, entre cantiga d'amigo paralelística e não-paralelística; e desvaloriza os elementos tradicionais e arcaicos da variedade paralelística. Paden junta-se deste modo à corrente de opinião veiculada, entre outros, por José Carlos Miranda, que vê a cantiga d'amigo essencialmente como uma criação isolada da elite trovadoresca galego-portuguesa da segunda geração ${ }^{5}$. Um artigo anterior de Paden, sobre a cronologia dos géneros, já acolhia esta ideia ${ }^{6}$.

6 Neste contexto, é compreensível que o autor revele algum incómodo face à minha contraposição musical entre cantiga d'amigo e cantiga d'amor ${ }^{7}$. Consequentemente, Paden acabou por dedicar um terceiro trabalho às minhas edições de Martin Codax e de $\mathrm{D}$. Dinis, procurando insinuar que o alegado contraste musical entre os dois é duvidoso e que, portanto, não constitui argumento contra a sua visão, essencialmente estática e simétrica, dos dois géneros amorosos ${ }^{8}$.

7 Em suma, Paden declara-se incompetente para discutir a notação musical, mas, considerando as incertezas que existem na interpretação rítmica da canção trovadoresca, crê que exagero ao contrapor nesse aspecto os dois repertórios; faz tábua-rasa de toda uma linhagem filológica de discussão do ritmo acentual na poesia ibérica medieval - por vezes com referência directa a Martin Codax - mas não aceita a minha proposta de que a igualdade silábica dos versos pode estar subordinada a regularidades acentuais, na medida em que a regularidade silábica é a norma em Codax e que a regularidade dos acentos lhe surge editorial e analiticamente forçada. Desqualifica a comparação de Codax com D. Dinis devido ao facto de a minha edição do Pergaminho Sharrer incluir uma dose 
importante de reconstrução musical, embora admita que a minha análise comparativa se baseia somente nos segmentos melódicos originais.

Devo dizer que vários trabalhos que publiquei entre 1998 e 2009 já respondiam à substância das objecções de Paden com a distinção entre variedades de cantiga d'amigo e a reafirmação da polaridade estética entre a cantiga paralelística e a cantiga d'amor ${ }^{10}$. Neste contexto, vale a pena lembrar o que diz Alan Deyermond sobre as variedades de cantiga d'amigo: "as cantigas de amigo paralelísticas são tão diferentes das restantes - a diferença é maior do que a existente entre as não-paralelísticas e as cantigas de amor que [as de amigo] não podem ser estudadas de forma útil como um grupo único"11.

\title{
Posição do problema: as melodias de Martin Codax e a cultura oral feminina
}

Ouçamos ainda Deyermond sobre a identidade da cantiga paralelística:

\begin{abstract}
"As cantigas de amigo paralelísticas apresentam sérias dificuldades tanto para aqueles que acreditam que elas derivam directamente de poesia autêntica de mulheres, como para aqueles que as vêem como artefactos masculinos sem relação com a tradição oral feminina. [...] Se as cantigas de amigo paralelísticas são invenções masculinas [...] como explicar as suas semelhanças verbais com as kharjas, os villancicos e os refrains franceses? Há muito que James Monroe demonstrou [...] que cada uma dessas tradições líricas tem o seu sistema formulaico, e que os sistemas têm tal semelhança entre si que só podem ter uma origem comum, que ele localiza na tradição oral em Latim vulgar [...]. As suas conclusões foram reforçadas pelo estudo sobre cantigas de amigo e kharjas levado a cabo por Martha Schaffer"12.
\end{abstract}

Considerando a sua posição, por nós partilhada, de que estas cantigas paralelísticas são uma reelaboração literária masculina de uma autêntica tradição oral feminina, podemos perguntar-nos se nessa reelaboração há traços musicais que possam ser atribuídos à suposta oralidade de raiz - e constituir, portanto, uma marca de género, a par da voz poética, da versificação paralelística, do arcaísmo linguístico e das palavras-chave que remetem para o antigo universo da canção de mulher.

11 Para respondermos, ainda que de maneira tacteante e hipotética, a esta questão, podemos somente recorrer a seis melodias, atribuídas a Martin Codax - de quem, aliás, ao certo nada se sabe $^{13}$. A amostra musical é muito curta, e identificar nela um substracto estilístico é tarefa problemática (especialmente se esse substracto for documentalmente evanescente). No entanto, desde há exactamente cem anos que estas melodias alimentam especulações ou servem para firmar convicções sobre a sua paternidade estética.

Esta paternidade foi em primeiro lugar atribuída, indirectamente, ao povo da Galiza. 0 cónego Santiago Tafall Abad, que escreveu em 1917, viu em três das cantigas um eco do alalá galego - tipo de canção pausada, não acompanhada, constituída por frases de âmbito estreito, por vezes com ornamentação pontual ou uso de sílabas soltas ${ }^{14}$. Também para Higinio Anglés, em 1958, as cantigas, embora de gosto refinado, recordavam, "de certa maneira, outras melodias do folclore tradicional da Galiza, cantadas com pouco texto e deixando que a música supra o sentimento das palavras no melisma final de frase" ${ }^{15}$. Na mesma linha, José López-Calo opinava em 1982 que estas melodias, se bem que de género culto, encerrariam "uma melancolia absolutamente única [...], intimamente aparentada com o espírito de algumas das mais típicas músicas populares da Galiza"16. Já para Julián Ribera, em 1925, seguido por Eduardo Martínez Torner em 1928, as melodias codacianas 
teriam relação com as Cantigas de Santa Maria e derivariam, por consequência, da escola musical andaluza, mediante simplificação ${ }^{17}$. Em alternativa, Isabel Pope, em 1934, procurou atribuir à Igreja a paternidade do estilo; foi nisso seguida por Mário de Sampayo Ribeiro, em 1941, e José Augusto Alegria, em $1968^{18}$. De forma mais matizada, em 1998, a filiação clerical das cantigas de Codax foi ainda explorada por Charles Brewer ${ }^{19}$. Finalmente, William Paden, em 2015, avançou a ideia de que o estilo musical codaciano seria próximo do encontrado na cantiga d'amor, associada ao trovadorismo aristocrático ${ }^{20}$

13 A música de Martin Codax presta-se, portanto, a interpretações diversas, consoante as inclinações de cada um, sem que nessa hipotética identidade musical se tenha até agora tentado abrir espaço para uma possível raiz na cultura oral feminina. De alguma forma todos os autores citados se apoiaram em dados objectivos, exagerando, porém, a sua importância de modo a obliterar as hipóteses concorrentes.

14 O elemento popular é sugerido pelo âmbito melódico estreito e pela forma repetitiva das melodias. O âmbito chega a ser inferior ao intervalo de quinta perfeita na cantiga IV, "Ai Deus, se sab'ora meu amigo" (Ex. 1) ${ }^{21}$.

Exemplo 1: Martin Codax, cantiga IV, "Ai Deus, se sab'ora meu amigo" (excerto), em transcrição do autor (1986).

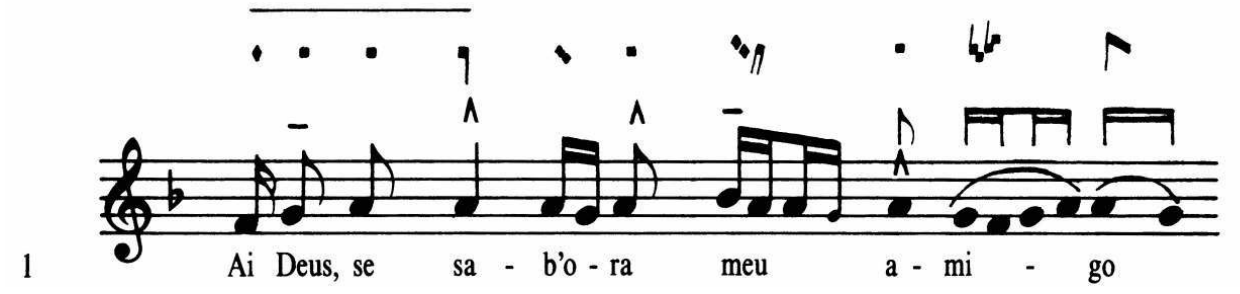

15 A repetitividade pode ser ilustrada pela cantiga V, "Quantas sabedes amar amigo": não só a frase musical que veicula o primeiro verso surge repetida (com ornamentação adicional) com o segundo verso, como o seu segmento final reaparece na segunda parte do refrão (Ex. 2) 22 . 
Exemplo 2: Martin Codax, cantiga V, "Quantas sabedes amar amigo", em transcrição do autor (1998/2017).

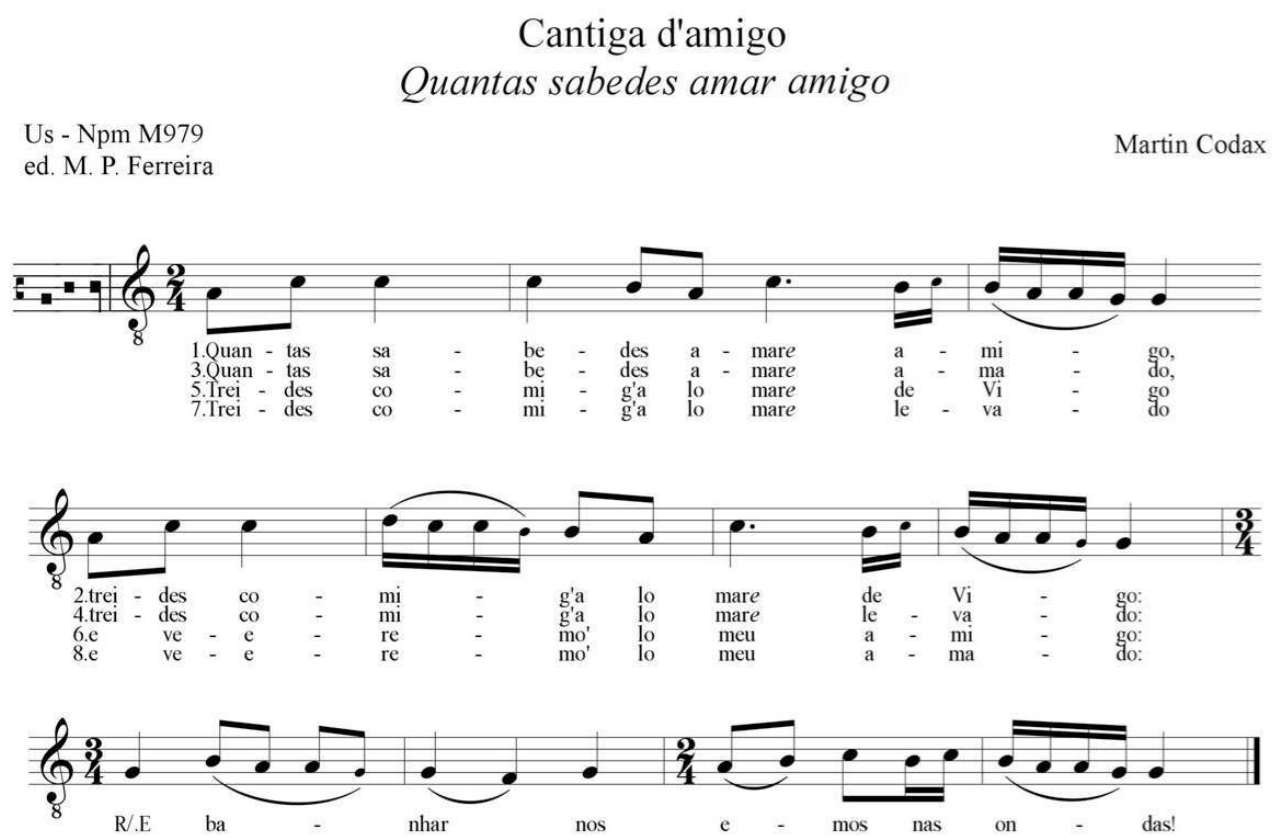

16 A proximidade com as Cantigas de Santa Maria é dada pela presença de fórmulas comuns (tal como, no Ex. 2, a entoação lá-dó-dó com o ritmo breve-breve-longa, que é replicada em várias Cantigas de Santa Maria), fórmulas que remetem provavelmente para um substrato jogralesco ${ }^{23}$.

17 A ligação à música eclesiástica é sugerida por elementos constitutivos da salmodia e por perfis intervalares compatíveis com a modalidade gregoriana. De facto, as melodias do Pergaminho Vindel usam fórmulas iniciais, mediais e finais associadas ao $3^{\circ}$ e $8^{\circ}$ tons $\mathrm{e}$ evidenciam um forte parentesco com o Tritus e Tetrardus plagais, numa versão arcaica. 0 caso mais flagrante é o uso do terceiro tom salmódico como base para o contorno melódico da frase inicial na cantiga "Ondas de mar de Vigo" (Ex. 3) ${ }^{24}$.

Exemplo 3: Terceiro tom salmódico, segundo Amerus (1271), confrontado com Martin Codax, cantiga I, “Ondas do mar de Vigo" (excerto), em transcrição do autor (2008).

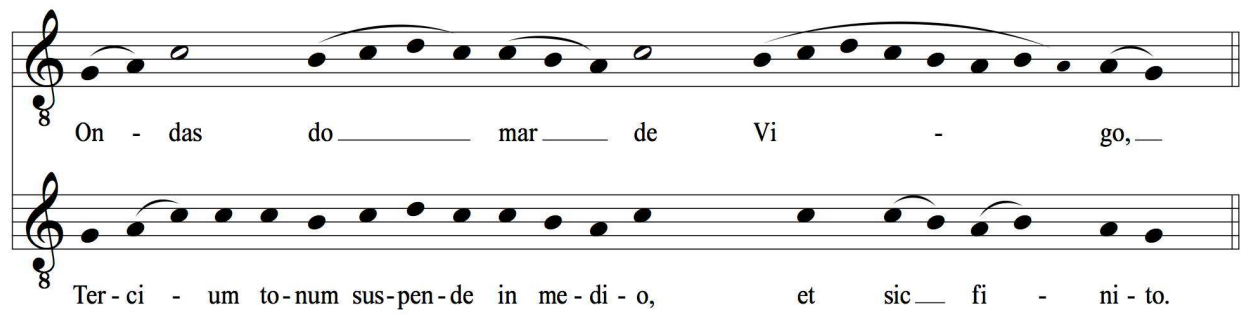

18 A proximidade à música cortês de tradição trovadoresca entrevê-se quer na ornamentação dos finais de frase ou de passagens mais extensas logo após as primeiras notas, quer nas regularidades de pulsação que é possível entrever ou supor com fundamento. Um estilo ornamental plausivelmente conjugado com uma pulsação isócrona 
pode ser lido nas cantigas mais morosas de Codax, como a última do ciclo (Ex. 4), e também nas cantigas de amor de Dom Dinis conservadas no Pergaminho Sharrer (Ex. 5) ${ }^{25}$. Em ambos os casos, grupos de entre três e cinco notas podiam ter sido cantados em intervalos de tempo aproximadamente equivalentes.

Exemplo 4: Martin Codax, cantiga VII, "Ai ondas que eu vin veer" (excerto), em transcrição do autor (1986). Os valores rítmicos após a barra tracejada são apenas indicativos.

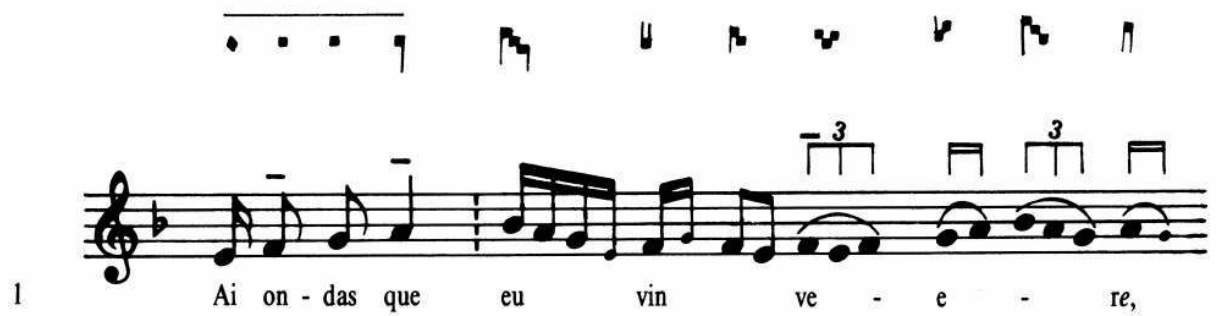

Exemplo 5: Dom Dinis, cantiga "O que vos nunca cuidei a dizer", segundo o Pergaminho Sharrer (excerto), em transcrição do autor (2005/2016). As pequenas barras que encimam a pauta sugerem o retorno de uma pulsação.

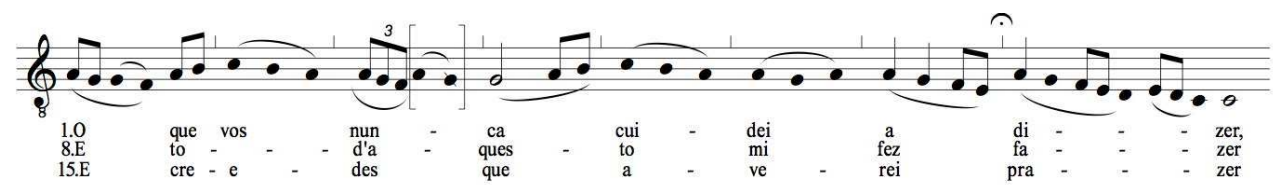

As melodias foram abordadas de forma analítica moderna só a partir da década de 1980. Um pequeno estudo do musicólogo argentino Gerardo Huseby sobre a primeira cantiga, "Ondas do mar de Vigo", tendo embora como horizonte a refutação da tese andaluza de Ribera a favor do reconhecimento de uma matriz modal enraizada na monodia eclesiástica, evidenciou as conexões da melodia quer com a Cantiga de Santa Maria $\mathrm{n}^{\circ} 73$, quer com a salmodia gregoriana ${ }^{26}$.

Quase simultaneamente, Ismael Fernández de la Cuesta redescobria em Nova Iorque o Pergaminho Vindel, inacessível desde a sua descoberta. Num trabalho de sete densas páginas datado de 1982, o musicólogo espanhol apresenta-o, descreve-o e fornece a primeira transcrição (puramente melódica) feita a partir do documento original, acompanhada de novas fotografias ${ }^{27}$. No seu livro de história da música medieval em Espanha, publicado pouco depois, comenta assim a primeira cantiga de Codax:

"O primeiro verso da estrofe inicia o tema melódico. O tema é retomado com alguma variante deixando a cadência em suspenso para passar ao estribilho. Este recolhe também um fragmento do tema iniciado no primeiro verso, de maneira que [...] se estabelece uma espécie de concatenação de pequenas células que passam de um verso a outro da estrofe, e da estrofe ao estribilho voltando logo de novo à cabeça. Não é difícil ver nessas pequenas células melódicas alguma semelhança com certas fórmulas ou centões litúrgicos [...]"28.

Surpreende-se assim nesta melodia um trabalho de composição formulaica, traço intimamente associado à oralidade. Foi este aspecto de oralidade imanente que me interessou nas cantigas, levando-me à escrita d' 0 som de Martin Codax ${ }^{29}$. Aí se abordam as melodias não como instâncias abstractas, mas antes como concretizações sintéticas influídas quer pelos processos mnemónicos, quer pelos contextos poéticos; e as suas notações, não tanto como projecções de sistemas de escrita preexistentes, mas como representações aturadas da particularidade do discurso musical. De facto, a chave para a 
correcta interpretação do repertório não está, a meu ver, na sua alegada filiação popular, andaluza, eclesiástica ou cortesã, mas na sua matriz oral e regional, que permitiu incorporar, transformados, elementos localmente preexistentes associados à cultura feminina (não obstante o carácter supraregional dos seus antecedentes) e gerar um perfil artístico único no panorama europeu.

22 A busca de traços musicais de oralidade abarcou, na investigação que levei a cabo em meados dos anos oitenta, não só os materiais melódicos convocados (melodias-tipo, fórmulas) mas também a padronização rítmica (associada ou não a conteúdos mélicos); a conexão entre acentuação musical e acentuação textual e a coexistência de diferentes temporalidades, relacionadas com diferentes segmentos da estrutura poética. Procurouse, em suma, perceber o que, na melodia final, advém, não de uma imaginação projectada na superfície abstracta da escrita, mas da memória colectiva e do condicionamento literário.

Este foi um programa analítico ambicioso, mas finalmente fecundo quer nas conclusões retiradas, quer na densidade informativa da edição resultante; deparou-se, porém, com uma dificuldade imprevista, revelada pelo exame paleográfico: o facto de, entre as seis melodias, quatro terem sido apontadas por um copista e as duas restantes por outro; possivelmente nesta mesma ordem.

Há, portanto, que analisar separadamente os dois grupos de cantigas. Felizmente, há permutas de figuras musicais, em contextos semelhantes, ao longo das cantigas I, IV, V e VII, o que permite desenhar um quadro de equivalências rítmicas; como alguns dos padrões e do material melódico lhes são comuns, consegue-se aperceber nesse conjunto, de forma imanente, coerência suficiente para uma caracterização estilística. Mas se quatro melodias são poucas para sustentar um juízo de conjunto, dispor de duas apenas quase impossibilita generalizações. Acresce que uma destas melodias, a da cantiga III, está incompleta, o que torna ainda mais arriscada a sua interpretação.

Apesar de tudo, acabei por arriscar essa indagação de sentido. Do ponto de vista semiótico, concluí que as cantigas I, IV, V e VII usam uma notação mensural não modal, enquanto o copista das cantigas II e III recorreu a uma notação modal pré-franconiana (entendendo-se aqui por "modal" uma notação que procura significar algum dos modos rítmicos da tradição polifónica parisiense); esta última notação é interpretável somente por referência a outros repertórios. Tal conclusão é substancialmente retida no último estudo musicológico do Pergaminho Vindel, um trabalho cuidadoso assinado por Antonio Calvia, que acompanha o facsímile de luxo recentemente publicado ${ }^{30}$.

Apercebemo-nos que estas últimas melodias, as das cantigas II e III, quase não marcam temporalmente a distinção entre "base" e "coda" do verso paralelístico, reservando o contraste de temporalidades para o refrão. Sucedendo algo de semelhante na cantiga V, tal facto poderá dever-se ao carácter vivaz de todas três. Mais significativo é que não recorram à alternância irregular de valores breves e longos, com uso de fórmulas e o emprego de padrões rematados por longa - um estilo que apelidei de "ritmo rapsódico" ${ }_{31}$. Num estudo analítico publicado em 2009, evidenciei ainda que as cantigas I, IV, V e VII partilham motivos musicais que estão ausentes das cantigas II e III, sugerindo diferente autoria para cada um dos grupos ${ }^{32}$. 


\section{Excurso: releitura de duas cantigas de Martin Codax}

Gostaria de aproveitar esta ocasião para revisitar essas duas cantigas, à luz de duas observações paleográficas e de dois argumentos musicológicos.

\section{Exemplo 6: Martin Codax, cantiga II, “Mandad'ei comigo", no Pergaminho Vindel (pormenor).}

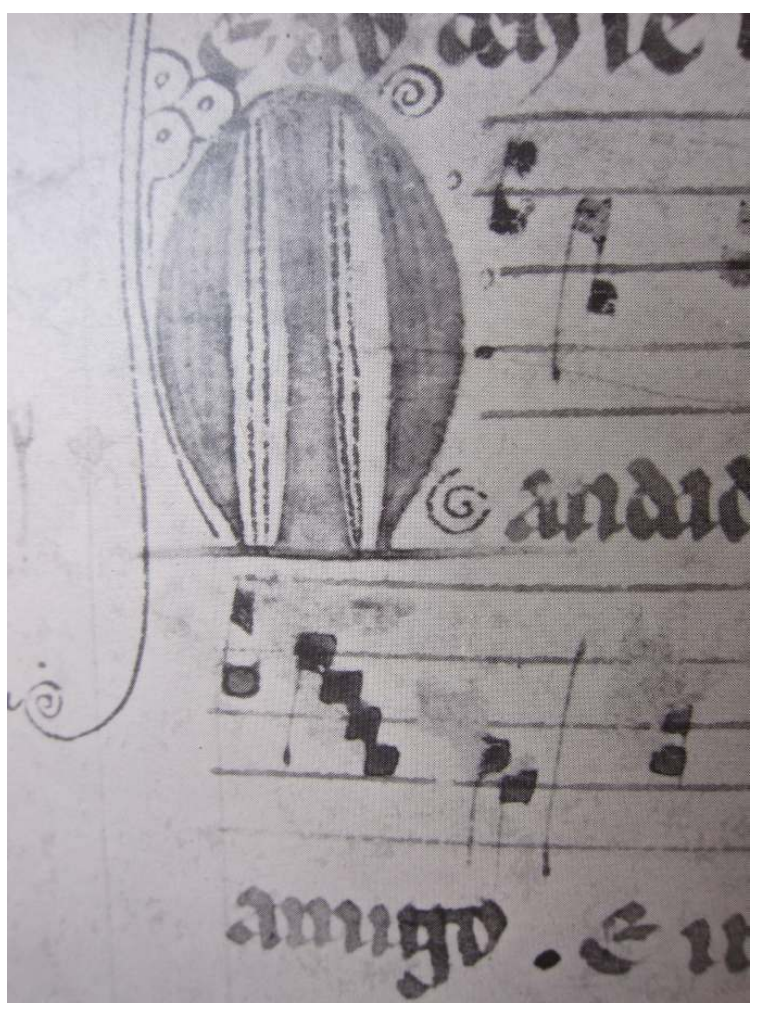

Começo pelas observações paleográficas. No Pergaminho Vindel o final do segundo verso da cantiga II, "Mandad'ei comigo", foi escrito sobre rasura (Ex. 6). Nessa reescrita, sobre a palavra amigo, há apenas duas figuras musicais, em vez das três expectáveis - uma por sílaba. Consequentemente, uma das figuras tem que ser cindida em duas. Os editores têm concordado em cindir a última figura: mas de que figura se trata? Eu interpretei-a, aliás como fez recentemente Calvia, como uma fusão de plica (com dois traços verticais paralelos) e de nota simples. Olhando novamente para as ampliações fotográficas, fico agora convencido de que o copista aproveitou algo da camada rasurada e lhe acrescentou um ou ambos os traços verticais para significar que cada uma das duas notas ficaria a corresponder a uma sílaba. Não se trataria, portanto, de um desenho notacional feito com especial intenção melódica. Assim sendo, passo a subscrever neste ponto a anterior leitura de Higinio Anglés e de Ismael Fernández de la Cuesta, ou seja: haveria aí só duas notas, sem nota ornamental de permeio.

A segunda observação paleográfica diz respeito à cantiga seguinte, "Mia irmana fremosa". Esta é uma das cantigas cuja estrutura acentual tem sido defendida por vários filólogos. Um destes é Stephen Parkinson, o qual, após propor critérios objectivos para identificação de uma métrica acentual nos textos poéticos galego-portugueses, identificou sessenta e três cantigas d'amigo que cumprem esses critérios, incluindo quatro composições de Martin Codax. Na sua análise, "Mia irmana fremosa" é caracterizada quer 
pela irregularidade na medida silábica dos versos, quer pela regularidade da respectiva acentuação (Ex. 7) ${ }^{33}$.

Exemplo 7: Martin Codax, cantiga III, “Mia irmana fremosa, treides comigo", segundo Parkinson, sobre texto fixado por Cohen (2003).

\begin{tabular}{|l|l|l|}
\hline Martin Codax & acentos & sílabas \\
\hline Mia irmana fremosa, treides comigo & 4 & $11^{\prime}$ \\
\hline a la igreja de Vigo u é o mar salido & 4 & $14^{\prime}$ \\
\hline e miraremos las ondas & 2 & $7^{\prime}$ \\
\hline Mia irmana fremosa, treides de grado & 4 & $11^{\prime}$ \\
\hline a la igreja de Vigo u é o mar levado & 4 & $14^{\prime}$ \\
\hline e miraremos las ondas & 2 & $7^{\prime}$ \\
\hline a la igreja de Vigo u é o mar levado & 4 & $14^{\prime}$ \\
\hline e verrá i mia madr<e> e o meu amado & 4 & $12^{\prime}$ \\
\hline e miraremos las ondas & 2 & $7^{\prime}$ \\
\hline a la igreja de Vigo u é o mar salido & 4 & $14^{\prime}$ \\
\hline e verrá i mia madr<e> e o meu amigo & 4 & $12^{\prime}$ \\
\hline e miraremos las ondas & 2 & $7^{\prime}$ \\
\hline
\end{tabular}

Para o autor, a uniformização da medida dos versos exigiria um enorme esforço editorial; não se trataria, contudo, de uma composição conceptualmente polimétrica, mas de um poema livremente estruturado em torno de acentos regulares conducentes à rima: um tipo de versificação alternativo àquele em que se requerem versos com um número determinado de sílabas e onde apenas se dá atenção ao acento final de verso, sobre a rima.

Parkinson tomou aqui como referência textual a já clássica edição das cantigas d'amigo de Rip Cohen ${ }^{34}$, autor que, defendendo embora o tradicionalismo da cantiga d'amigo, tem revelado uma persistente alergia ao conceito de versificação acentual. Cohen acaba, aliás, de propor uma nova edição do cancioneiro de Martin Codax, na qual mantém a postura de só atender, antes da rima, às regularidades de cômputo silábico ${ }^{35}$. Embora surja como novidade, a fixação de texto aí proposta representa, na minha opinião, um retrocesso. De facto, ignora quer a escansão silábica revelada pela notação musical, quer as implicações da normalização, observada por Celso Cunha, imposta pelos compiladores tardios ${ }^{36}$; desvaloriza a lição do Pergaminho Vindel face à dos apógrafos italianos, o que se reflecte quer no estema proposto (praticamente idêntico ao publicado em 1980 por Barbara Spaggiari ${ }^{37}$ ) quer nas opções editoriais. A cantiga $V$, por exemplo, fica praticamente igual à leitura de Stephen Reckert, retomada duas décadas mais tarde pelo Centro Ramon Piñeiro $^{38}$. A única cantiga em que mostra ousadia é precisamente a terceira (Ex. 8): 
Exemplo 8: Martin Codax, cantiga III, “Mia irmana fremosa, treides comigo", segundo Cohen (2016).

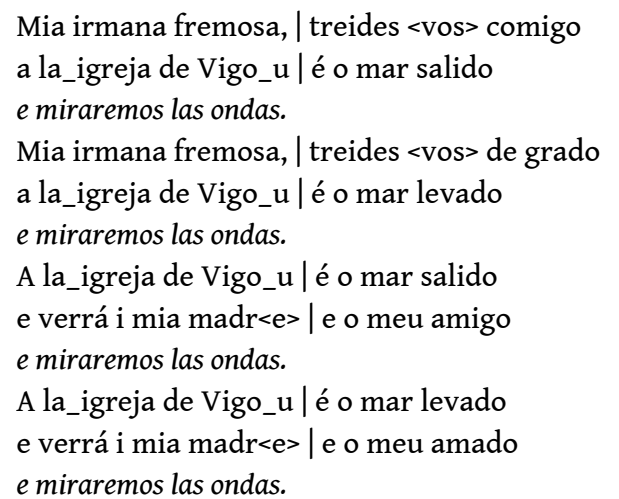

Ora, acontece que a crença na invariabilidade, nos dísticos, do esquema métrico $\left[6^{\prime}+5^{\prime}\right]$, conjugada com a recusa em reconhecer validade métrica ao bissilabismo de mia (evidenciado pelo Pergaminho Vindel), leva ao acrescento, após treides, da sílaba <vos>, ao arrepio de todos os manuscritos, desvio este que é dificilmente compensado pelo fervor linguístico a favor da forma reflexiva do verbo traer.

Exemplo 9: Martin Codax, cantiga III, "Mia irmana fremosa, treides comigo", no Pergaminho Vindel (pormenor).

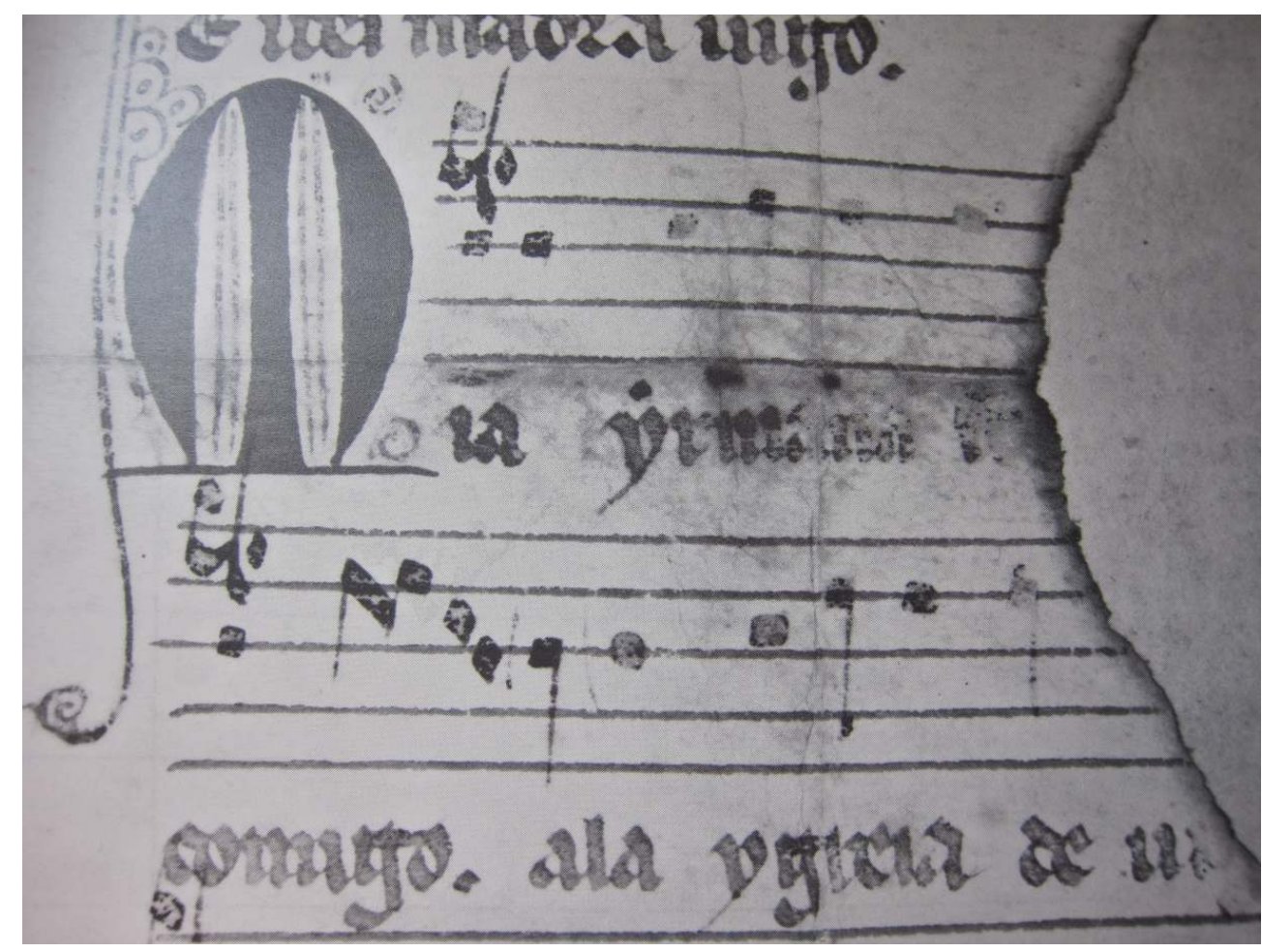

Retomemos então a análise paleográfica (Ex. 9). Na frase inicial, a última nota antes da lacuna no manuscrito está tão esvaída que poderia ter exibido um traço à direita, como o que surge na repetição da frase na segunda pauta (mudando desse modo o punctum em virga). De qualquer modo, a alternância hoje observável entre virga-punctum-punctum e virga-punctum-virga podia ter sido entendida apenas como variante gráfica, como sucede nas Cantigas de Santa Maria. 

sos como Barbara Spaggiari, Luiz Fagundes Duarte e Domingos Prieto Alonso e é retida por Rip Cohen na sua última leitura do texto ${ }^{40}$. Porém, Spaggiari lê nos dísticos três esquemas métrico-acentuais diferentes, todos com acento medial na sexta sílaba mas oscilando entre continuidade ou descontinuidade a meio do verso, quatro a cinco acentos, e onze a doze sílabas métricas; Fagundes Duarte e Prieto Alonso assumem nos dísticos um esquema de escansão prosódica organizado em torno de uma cesura medial após a sexta sílaba métrica ( $6^{\prime}$ ou 6), com dois acentos por cada membro do verso; enquanto o último editor assume doze sílabas métricas em cada verso, com cesura invariável no mesmo ponto. Stephen Parkinson, em contrapartida, assume nesta cantiga - que considera, como Fagundes Duarte, estruturada em torno de $2+2$ acentos - a elasticidade, entre onze e catorze sílabas, da medida do verso encontrada nas estrofes, contagem silábica que é porém considerada conceptualmente irrelevante (Ex. 7) ${ }^{41}$.

maioria das interpretações acima referidas ressentem-se da rigidez na divisão interna dos versos em hemistíquios, sem ter em conta a possibilidade de adição ou supressão de uma nota inicial, ou ainda, de desdobramento articulatório de um grupo de notas ou de uma só nota de longa duração $0^{42}$. Acresce que a relação texto-música revelada pelo apontador do Pergaminho Vindel tende a ser tratada enquanto aspecto supletivo e não enquanto faceta estrutural neste tipo de cantiga, revelando o prolongamento de um 
preconceito anacrónico que cinde o jogral em duas identidades incomunicantes, a do poeta e a do cantor.

Pode ainda admitir-se que a cantiga, em vez de exemplificar uma métrica acentual pura, tivesse natureza silábico-acentual, ou seja, decorresse de um tipo de versificação em que fossem conscientemente padronizados tanto o cômputo silábico (uniforme ou biforme) como a diferenciação acentual ao longo dos versos. Se adoptarmos, de acordo com o testemunho medieval, tanto a leitura bissilábica de mia (concretização de uma possibilidade métrica e não mera diérese musical de um monossílabo) como a sinalefa em la_igreja, facilmente se obterão nos dísticos versos ímpares de doze sílabas métricas e versos pares de treze sílabas (em correspondência com a primeira e segunda frases musicais, respectivamente), todos com quatro acentos ${ }^{43}$. A segunda frase musical varia, em relação à primeira, na entoação inicial e sobretudo no segmento final, o que torna possível a polimetria. Note-se de passagem que o aspecto acentual só é pertinente, em Martin Codax, na análise das estrofes ${ }^{44}$.

Na cantiga III os acentos dos diferentes versos dos dísticos só aparentemente estão desencontrados entre si, pois nada impede que estivessem verticalmente sobrepostos sob a música, a exemplo do primeiro acento sobre irmana e igreja; o acento poético medial recairia alternadamente na sexta ou na sétima sílaba do verso, mas sempre no mesmo ponto da frase musical: as acentuações da melodia regulariam os acentos métricos. As restantes sílabas do verso seriam livremente distribuídas em torno destes nós acentuais. Contudo, para gerar uma interpretação isossilábica (doze sílabas métricas) abarcando versos tanto ímpares como pares, basta supor, seguindo Ferreira da Cunha e a equipa do Centro Ramón Piñeiro, uma sinalefa ou elisão no final do primeiro segmento dos versos pares (Vigo_u ou Vig'u; madr'e); a melodia original para este segmento perdeu-se, pelo que não se pode saber qual das hipóteses de leitura é mais justa, nem em que monossílabo recairia a acentuação musical. Em todo o caso, o resultado métrico e acentual é muito regular, tendo em conta a relação com a música (Ex. 10).

Exemplo 10: Martin Codax, cantiga III, “Mia irmana fremosa, treides comigo”, em nova leitura

\begin{tabular}{|c|c|c|c|}
\hline Martin Codax & acentos & sílabas & alternativas \\
\hline Mia irmana fremosa, treides comigo & 4 & $12^{\prime}$ & \\
\hline a la_igreja de Vigo u é o mar salido & 4 & $13^{\prime}$ & u é ? (Vigo_u é: 12 ') \\
\hline e miraremos las ondas & & $7^{\prime}$ & \\
\hline Mia irmana fremosa, treides de grado & 4 & $12^{\prime}$ & \\
\hline a la_igreja de Vigo u é o mar levado & 4 & $13^{\prime}$ & u é ? (Vigo_u é: 12 ') \\
\hline e miraremos las ondas & & $7^{\prime}$ & \\
\hline a la_igreja de Vig' u é o mar levado & 4 & $12^{\prime}$ & \\
\hline e verrá i mia madr[e] e o meu amado & 4 & $13^{\prime}$ & e o ? (madr'e o / madre, o: 12 ') \\
\hline e miraremos las ondas & & $7^{\prime}$ & \\
\hline
\end{tabular}




\begin{tabular}{|l|l|l|l|}
\hline a la_igreja de Vig' u é o mar salido & 4 & $12^{\prime}$ & \\
\hline e verrá ́ mia madr[e] e o meu amigo & 4 & $13^{\prime}$ & e o ? (madr'e o / madre, o: 12') \\
\hline e miraremos las ondas & & $7{ }^{\prime}$ & \\
\hline
\end{tabular}

41 Voltemos agora a nossa atenção para os argumentos. O primeiro é retirado d' 0 som de Martin Codax: "admitindo que a unidade de medida poderia variar consoante o objecto a que se aplicasse, teremos também de admitir", argumentei então, "que a duração por ela instituída se poderia desdobrar em várias temporalidades"; contudo, essa diferenciação não se espelharia normalmente na notação musical,

"porquanto o copista medieval [...] não se colocava na posição de observador externo ao desenrolar da melodia; ele próprio a entoava, seguindo as suas eventuais mudanças de velocidade, pelo que não haveria, para ele, variação da unidade de tempo, mas apenas variações do próprio movimento" ${ }^{45}$.

Assim sendo, a homogeneidade da notação pode esconder variações de velocidade na sua execução. Em 0 som de Martin Codax a exploração deste princípio ficou subordinado à identificação de objectos poéticos diferenciados que justificassem a mudança de temporalidade: ou seja, o refrão, por oposição aos dísticos estróficos, e os segmentos de verso gerados, nestes dísticos, pela técnica paralelística (o segmento base, que se retoma, mais a respectiva coda, com rima variável).

O segundo argumento é retirado de um artigo recente sobre a notação das Cantigas de Santa Maria ${ }^{46}$. Recordemos que esta notação, na versão dos códices hoje conservados no Escorial, é o tipo mais próximo do encontrado nos pergaminhos musicados da lírica profana galego-portuguesa. Sucedendo, como aí se demonstra nalguns casos, que os padrões rítmicos representam relações qualitativas e a extensão do período determina a duração real dos seus elementos, então a escrita de um padrão rítmico segue regras convencionais independentes da duração efectiva da unidade de tempo, a qual se sujeita, de forma elástica, à pulsação periódica. Isto permite diferentes subdivisões do compasso e a justaposição de padrões ternários correspondentes ao primeiro e segundo modos rítmicos (compasso de 3/4) e de padrões compactados correspondentes ao terceiro e quarto modos (compasso de 6/8) ou aos seus equivalentes duracionais, com as correspondentes acelerações ou retenções do tempo musical. Isto, independentemente de quaisquer mudanças que ocorram na natureza do material poético. O efeito cumulativo destes argumentos é o alargamento da latitude interpretativa das notações pré-franconianas quando aplicadas à monodia cortês. Na cantiga II, isto permitenos abordar o refrão com elasticidade temporal, mantendo a pulsação mas diminuindo a velocidade dos eventos através da alternância de 3/4 e de 6/8 (Ex. 11). 


\section{Cantiga d'amigo \\ Mandad'ei comigo}

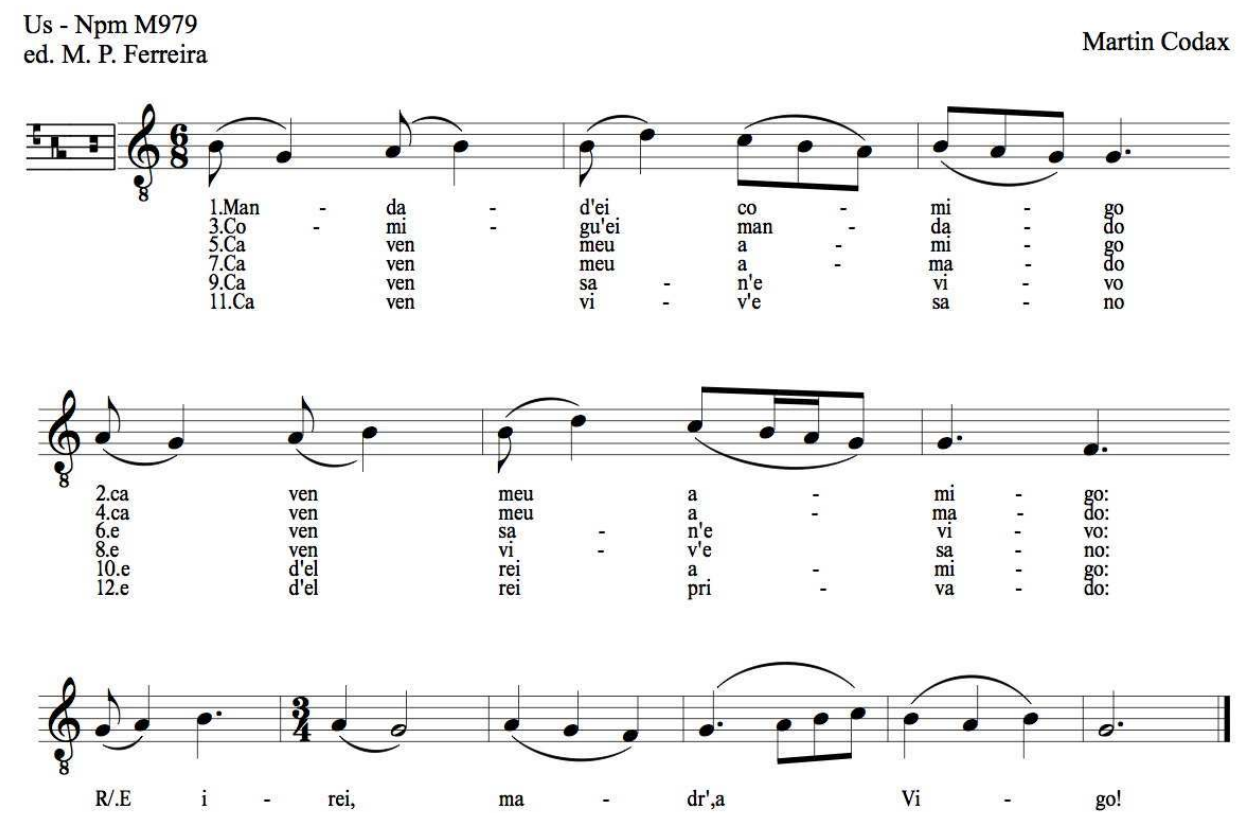

Na cantiga III, a mesma alternância produz nas estrofes não só uma aceleração pontual, mas também a possibilidade de, ao antecipar-se a sexta sílaba, fazer recair a sílaba tónica de fremosa sobre a pulsação musical, um alinhamento acentual que não era até agora evidente (Ex. 12). A solução encontrada, incluindo a dupla forma de entoação dos versos e a mobilidade da cesura poética, surge ajustada à letra e à notação do Pergaminho Vindel; é acentualmente coerente; e é, para mais, compatível quer com a elasticidade da medida silábica entre doze e treze sílabas, quer com uma interpretação métrica que atribua doze sílabas (divisíveis em 7'+4', 7+5' ou 6+6') a cada verso paralelístico. 
Exemplo 12: Martin Codax, cantiga III, “Mia irmana fremosa, treides comigo", em transcrição do autor (2017)

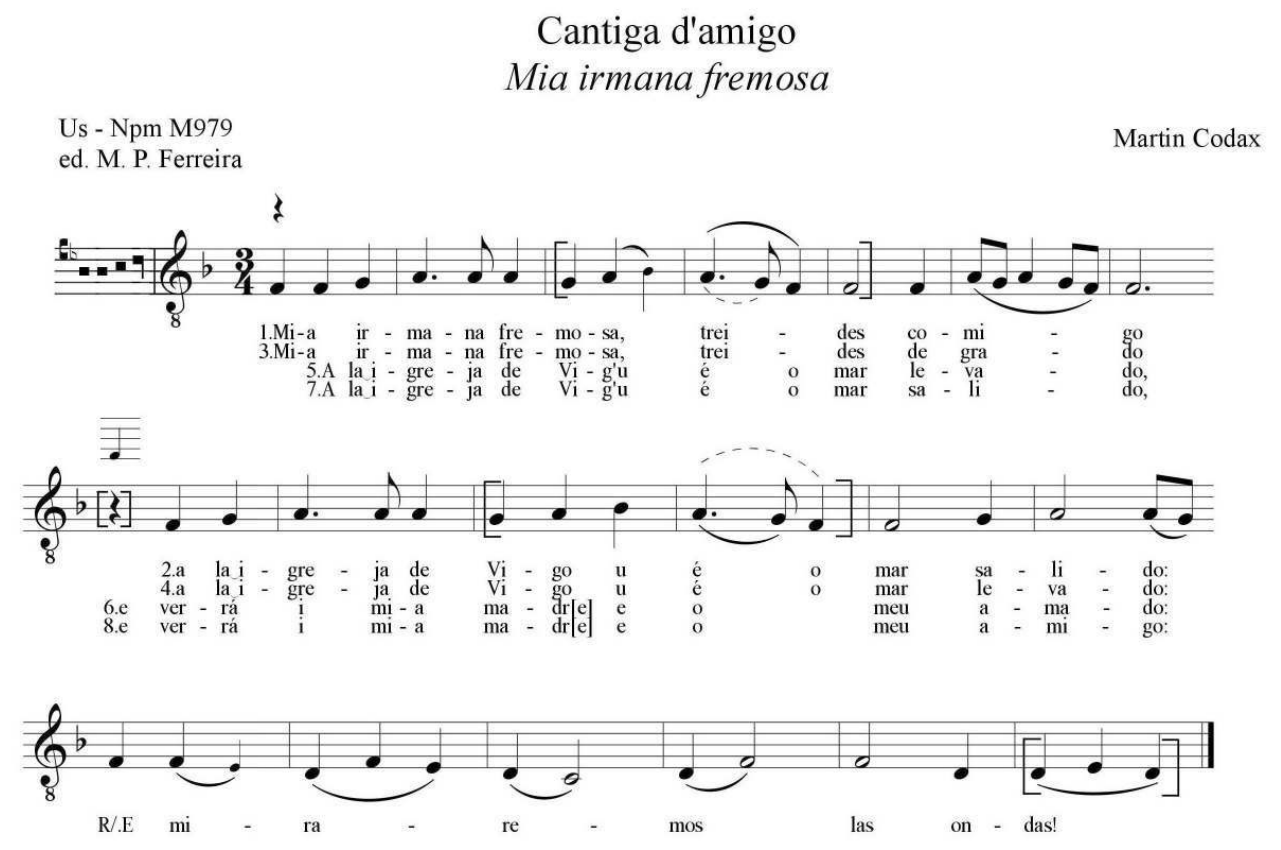

\section{Retoma: oralidade e canção de mulher}

Estamos agora em condições de voltar à questão inicial, a indagação sobre os traços musicais de uma oralidade primeva, associada à cultura feminina dos alvores da Idade Média. A invenção melódica desta música repousa na replicação, expansão e contracção de estruturas ou motivos preexistentes. Este processo é contudo comum às cantigas d'amor de Dom Dinis ${ }^{47}$. Trata-se de uma característica geral da composição musical nascida da oralidade, não sendo, portanto, própria do contexto paralelístico. A presença de um ritmo rapsódico é, em contrapartida, singular no contexto da época.

Recordemos que a igualdade na duração das notas do canto gregoriano tardio, a pulsação isócrona do cantus coronatus, os ritmos modais parisienses e os padrões rítmicos andaluzes são esquemas que organizam ou se sobrepõem ao material melódico, sem serem por este influenciados. Já o ritmo rapsódico é a marca deixada na linha do tempo pela justaposição de materiais pré-formados; é um traço arcaico, estreitamente vinculado à memória colectiva. Estando ausente do segundo grupo de cantigas, isso sugere que estava já a perder-se, entre as cantigas paralelísticas, na segunda metade do século XIII.

No primeiro grupo de cantigas há ainda a registar um âmbito melódico invulgarmente estreito, sendo que o refrão, de tendência expansiva, supera o âmbito dos dísticos. Podemos adicionalmente listar três características que se encontram quer no grupo do primeiro apontador, quer nas introduzidas pelo segundo: a grande repetitividade formal; a correlação entre a presença de nós acentuais nas estrofes e acentuações musicais implicadas por desenho melódico, prolongamento duracional ou retorno da pulsação; e a heterogeneidade das temporalidades em conexão com segmentos específicos das cantigas. 
49 A primeira característica tem como paralelos mais próximos na tradição europeia, com notação musical conservada, as danças de roda (caroles), muito populares na sociabilidade feminina ${ }^{48}$. Algo afim à segunda característica (a marcação acentual da rima em versos curtos) também aí se pode encontrar. Todas três estão ausentes da tradição propriamente trovadoresca.

Quais destes traços remontarão à tradição feminil presumivelmente imitada, e quais deles corresponderão ao investimento artístico dos jograis? A resposta terá de ser especulativa; mas ainda assim, poderá especular-se de maneira razoável, de acordo com os dados recolhidos. Nada impede que se imagine uma arcaica tradição de cantigas de mulher feita de melodias repetitivas, estreitas, recheadas de motivos pré-formados, coladas à lógica estrutural e acentual dos poemas, maioritariamente silábicas mas com floreios ocasionais, mormente em final de frase. Nada impede que se imaginem os jograis a transformar tal tradição no sentido de uma maior densidade ornamental, de uma maior diferenciação de temporalidades, de uma consciente intensificação retórica e da incorporação de fórmulas e motivos oriundos dos universos eclesiástico ou trovadoresco. Pode mesmo imaginar-se, como sugerem as cantigas do segundo apontador, que os jograis lograram expandir o âmbito melódico e variar os perfis rítmicos com prejuízo do elemento rapsódico, aproximando assim a cantiga paralelística da não-paralelística.

51 Tradicionalismo melo-rítmico, simplicidade formal, variedade de estados temporais, concentração do registo vocal, adesão à regularidade dos acentos, ornamentação terminal: estes são talvez os traços mais estáveis e salientes do estilo, quando comparado com a "maneira de proençal" tematizada por Dom Dinis: "maneira" que buscava, pelo contrário, a novidade melódica dentro de uma temporalidade tendencialmente uniforme; "maneira" de âmbito vocal expansivo e floreio livre, deslocalizado; "maneira" onde a acentuação musical, longe de ter um papel estruturante, flutuava ao sabor pontual da declamação ${ }^{49}$.

Por oposição ao universo provençal, era daqueles primeiros traços que, por entre a trama sonora do jogral, se desprendia ainda, sedutor e sempre apreciado, um potencial perfume de mulher.

\section{BIBLIOGRAFIA}

Fontes impressas

500 Cantigas d'Amigo. Edição crítica de Rip Cohen. Porto: Campo das Letras, 2003.

AMERUS - Practica artis musice. Ed. Cesarino Ruini. Corpus scriptorum de musica, vol. 25. [Roma]: American Institute of Musicology, 1977.

Cancionero musical. Ed., selección y armonización Eduardo Martínez Torner. Madrid: Instituto Escuela, 1928.

Cantigas d'Amigo dos trovadores galego-portugueses. Ed. José Joaquim Nunes. 3 vols. Coimbra: Imprensa da Universidade, 1926-1928. 
Cantigas do Mar de Vigo. Edición crítica das cantigas de Meendinho, Johan de Cangas e Martin Codax. Ed. Antonio Fernández Guiadanes. Santiago de Compostela: Centro Ramón Piñeiro, 1998.

Cantigas medievais galego-portuguesas: corpus integral profano. Ed. e Coord. Graça Videira Lopes. 2 vols. Lisboa: Biblioteca Nacional de Portugal / IEM / CESEM, 2016.

Estudos

ALEGRIA, José Augusto - A problemática musical das cantigas de amigo. Lisboa: Fundação Calouste Gulbenkian, 1968.

ANGLÉS, Higinio - La Música de las Cantigas de Santa María del Rey Alfonso El Sabio, vol. III/2. Barcelona: Diputación Provincial de Barcelona - Biblioteca Central, 1958.

BOYNTON, Susan - “Women's Performance of the Lyric Before 1500". in KLINCK, Anne; RASMUSSEN, Ann Marie (Eds.) - Medieval Woman's Song: Cross-Cultural Approaches. Philadelphia: University of Pennsylvania Press, 2002, pp. 47-65.

BREWER, Charles E. - "The Cantigas d'Amigo of Martin Codax in the Context of Medieval Secular Latin Song”. La corónica 26/2 (1998), pp. 17-28.

CALVIA, Antonio - “A música do Pergamiño Vindel”. in Pergamino Vindel. Barcelona: M. Moleiro, 2016, pp. 161-82.

COHEN, Rip - “In the Beginning was the Strophe: Origins of the Cantiga d'Amigo Revealed!". in LARANJINHA, Ana Sofia; MIRANDA, José Carlos (Coords.). Modelo: Actas do X Colóquio da Secção Portuguesa da Associação Hispânica de Literatura Medieval. Porto: Faculdade de Letras da Universidade do Porto, 2005, pp. 243-255.

COHEN, Rip - "Internal rhyme and the history of strophic song". Washington DC: Virtual Center for the Study of Galician-Portuguese Lyric, 2014. https://blogs.commons.georgetown.edu/ cantigas

CUNHA, Celso Ferreira da - O Cancioneiro de Martin Codax. Rio de Janeiro: Imprensa Nacional, 1956 (reimpressão: Cancioneiros dos trovadores do mar. Lisboa: Imprensa Nacional - Casa da Moeda, 1999).

CUNHA, Celso Ferreira da - "Sobre o texto e a interpretação das cantigas de Martin Codax". in Critique textuelle portugaise. Actes du coloque (Paris, 20-24 octobre 1981). Paris: Centre Culturel Portugais, 1986, pp. 65-83 (reimpressão: Cancioneiros dos trovadores do mar. Lisboa: Imprensa Nacional - Casa da Moeda, 1999, pp. 511-529).

CUNHA, Celso Ferreira da - "The Cantigas of Martin Codax - Edited with Commentary and Prolegomena". in Pergamino Vindel. Barcelona: M. Moleiro, 2016, pp. 285-305.

DEYERMOND, Alan - "Some Problems of Gender and Genre in the Medieval Cantigas". in OCAÑA, Antonio Cortijo; PERISSINOTTO, Giorgio; SHARRER, Harvey L. (Eds.) - Estudios galegos medievais. Santa Barbara: Centro de Estudios Galegos, Department of Spanish and Portuguese, University of California at Santa Barbara [Studia Hispanica Californiana, 1], 2001, pp. 43-59.

DUARTE, Luiz Fagundes - “Acerca do Ritmo nas Cantigas de Amigo”. in Actes du XVII Congrès International de Linguistique et Philologie Romanes. Aix-en-Provence: Université de Provence, 1986, vol. 8, pp. 225-236.

DUFFELL, Martin J. - “The Metric Cleansing of Hispanic Verse”. Bulletin of Hispanic Studies 76 (1999), pp. 151-68.

FERNÁNDEZ DE LA CUESTA, Ismael - "Les cantigas de amigo de Martín Codax". Cahiers de civilisation médiévale 25 (1982), pp. 179-185 e 4 lâminas. 
FERNÁNDEZ DE LA CUESTA, Ismael - Historia de la música española, 1. Desde los orígenes hasta el "ars nova". Madrid: Alianza Editorial, 1983.

FERREIRA, Manuel Pedro - 0 som de Martin Codax - Sobre a dimensão musical da lírica galegoportuguesa (séculos XII-XIV). Lisboa: Imprensa Nacional - Casa da Moeda, 1986.

FERREIRA, Manuel Pedro - “Codax revisitado". Anuario de estudos literarios galegos (1998), pp. 157-168.

FERREIRA, Manuel Pedro - "Musik und Betonung in cantigas d'amigo". in CRAMER, Thomas et alii (Eds.) - Frauenlieder - Cantigas de amigo. Stuttgart: S. Hirzel, 2000, pp. 247-257.

FERREIRA, Manuel Pedro - Cantus Coronatus - Sete cantigas d'El-Rei Dom Dinis. Kassel: Reichenberger, 2005.

FERREIRA, Manuel Pedro - (Dir.) - Antologia de Música em Portugal na Idade Média e no Renascimento. 2 vols., 2 CDs. Lisboa: Arte das Musas / CESEM, 2008.

FERREIRA, Manuel Pedro - Aspectos da Música Medieval no Ocidente Peninsular, vol. 1: Música palaciana. Lisboa: Imprensa Nacional - Casa da Moeda / Fundação Calouste Gulbenkian, 2009.

FERREIRA, Manuel Pedro - “Estrutura e ornamentação melódica nas cantigas trovadorescas”. in Aspectos da Música Medieval no Ocidente Peninsular, vol. 1: Música palaciana. Lisboa: Imprensa Nacional - Casa da Moeda / Fundação Calouste Gulbenkian, 2009, pp. 150-74.

FERREIRA, Manuel Pedro - "Jograis, contrafacta, formas musicais: cultura urbana nas Cantigas de Santa Maria”. Alcanate. Revista de Estudios Alfonsíes 8 (2012-2013), pp. 43-53.

FERREIRA, Manuel Pedro - "Editing the Cantigas de Santa Maria: Notational decisions". Revista Portuguesa de Musicologia, nova série, 1/1 (2014), pp. 33-52.

FERREIRA, Manuel Pedro - "Ler o Pergaminho Vindel: suporte; textos; autor". in LOPES, Graça Videira; FERREIRA, Manuel Pedro (Coords.) - Do canto à escrita: novas questões em torno da lírica galego-portuguesa. Lisboa: IEM/CESEM, 2016, pp. 19-28.

HILLIER, Paul; The Theatre of Voices - Cantigas from the Court of Dom Dinis (CD HMU 907129). Los Angeles: Harmonia Mundi USA, 1995.

HUSEBY, Gerardo Victor - "The common melodic background of 'Ondas do mar de Vigo' and CSM \#73". in Studies on the Cantigas de Santa Maria: Art, Music, and Poetry. Madison, Wis.: Hispanic Seminary of Medieval Studies, 1987, pp. 189-201.

LÓPEZ-CALO, José - La música medieval en Galicia. La Coruña: Fundación "Pedro Barrié de la Maza, conde de Fenosa", 1982.

LÓPEZ-CALO, José - “O feito diferencial galego na música. Idade Media e Renacemento". in o feito diferencial galego na música. Vol. II. Santiago de Compostela: A Editorial da Historia / Museo do Pobo Galego, 1998, pp. 9-39.

MASSINI-CAGLIARI, Gladis - "A notação musical como fonte para o estudo do ritmo lingüístico no período trovadoresco do português: as cantigas de amor de D. Dinis". in MASSINI-CAGLIARI, Gladis; MUNIZ, Márcio R. C.; SODRÉ, Paulo Roberto (Orgs.) - Série Estudos Medievais 2: Fontes [recurso electrónico]. Vol. I. Araraquara: Associação Nacional de Pós-Graduação e Pesquisa em Letras e Lingüística, 2009, pp. 63-79.

MIRANDA, José Carlos Ribeiro - “Calheiros, Sandim e Bonaval: uma rapsódia de amigo". Guarecer revista electrónica de estudos medievais 1 (2016), pp. 47-62 [texto inicialmente publicado em 1994 em edição de autor]. 
MIRANDA, José Carlos Ribeiro - "Le surgissement de la culture troubadouresque dans l'occident de la Péninsule Ibérique: Les genres, les thèmes et les formes”. in TOUBER, Anton (Ed.) - Le rayonnement des troubadours. Actes du colloque de l'Association Internationale d'Études Occitanes. Amsterdam: Rodopi, 1998, pp. 97-105.

MONARI, Giorgio - Le cantigas de amigo di Martin Codax e l'interpretazione del ritmo della monodia medievale. Roma: Nuova cultura, 2004.

MONGELLI, Lênia Márcia - "Fremosos cantos: reflexões metodológicas sobre a lírica galegoportuguesa". Bulletin du centre d'études médiévales d'Auxerre / BUCEMA [En ligne], Hors-série ${ }^{\circ}$ 2 (2008). http://cem.revues.org/9112 [\#18]

MONROE, James T. - "Formulaic Diction and the Common Origins of Romance Lyric Tradition". Hispanic Review 43 (1975), pp. 341-350.

MONTEAGUDO, Henrique et alii - Tres poetas medievais da Ría de Vigo: Martín Codax, Mendiño e Xohán de Cangas. Vigo: Editorial Galaxia, 1998.

MULLALLY, Robert - The Carole: A Study of a Medieval Dance. Farnham and Burlington, Vt.: Ashgate, 2011.

OLIVEIRA, António Resende de - "Para uma integração histórico-cultural do canto trovadoresco galego-português”. Máthesis 8 (1999), pp. 125-145.

PADEN, William D. - “The chronology of genres in medieval Galician-Portuguese lyric poetry". La corónica 26/1 (1997), pp. 183-201.

PADEN, William D. - "Principles of Generic Classification in the Medieval European Lyric: The Case of Galician-Portuguese”. Speculum 81/1 (2006), pp. 76-96.

PADEN, William D. - "On the Music of Galician-Portuguese Secular Lyric: Sources, Genres, Performance”. in D'EMILIO, James (Ed.) - Culture and Society in Medieval Galicia: A Cultural Crossroads at the Edge of Europe. Leiden: Brill, 2015, pp. 862-893.

PARKINSON, Stephen - "Concurrent Patterns of Verse Design in the Galician-Portuguese Lyric". in WHETNALL, J.; DEYERMOND, A. (Eds.) - Proceedings of the Thirteenth Colloquium [PMHRS, 51]. London: Department of Hispanic Studies, Queen Mary, University of London, 2006, pp. 19-38.

PARKINSON, Stephen - "Métrica acentual nas cantigas de amigo". in LOPES, Graça Videira; FERREIRA, Manuel Pedro (Coords.) - Do canto à escrita: novas questões em torno da lírica galegoportuguesa. Lisboa: IEM/ CESEM, 2016, pp. 29-42.

POPE, Isabel - "Medieval Latin Background of the Thirteenth-Century Galician Lyric". Speculum 9 (1934), pp. 3-25.

PRIETO ALONSO, Domingos - "A métrica acentual na cantiga de amigo". in Estudos Portugueses: Homenagem a Luciana Stegagno Picchio. Lisboa: Difel, 1991, pp. 111-142.

RECKERT, Stephen; MACEDO, Hélder - Do cancioneiro de amigo, $1^{\text {a }}$ edição. Lisboa: Assírio \& Alvim, 1976. $3^{\text {a }}$ edição. Lisboa: Assírio \& Alvim, 1996.

RIBEIRO, Mário de Sampayo - “À margem do Cancioneiro de Manuel Joaquim”. Brotéria 33 (1941), pp. 383-417.

RIBERA, Julián - “De música y métrica gallegas”. in Homenage a Menéndez Pidal. Vol. III. Madrid, 1925, pp. 7-35.

SAMPEDRO Y FOLGAR, Casto - Cancionero Musical de Galicia. A Coruña: Fundación "Pedro Barrié de la Maza, Conde de Fenosa", 1942 (reimpressão: 1982). 
SCHAFFER, Martha E. - "The Galician-Portuguese Tradition and the Romance Kharjas". Portuguese Studies 3 (1987), pp. 1-20.

SCHUBARTH, Dorothé; SANTAMARINA, Antón - Cancioneiro Galego de tradición oral. A Coruña: Fundación “Pedro Barrié de la Maza, Conde de Fenosa”, 1982.

SCHUBARTH, Dorothé; SANTAMARINA, Antón - Cancioneiro Popular Galego, 3 vols. A Coruña: Fundación "Pedro Barrié de la Maza, Conde de Fenosa", 1984-1987.

SPAGGIARI, Barbara - "Il canzoniere di Martim Codax". Studi medievali, 3a. serie, 21/1 (1980), pp. 367-409.

SPAGGIARI, Barbara - "Un esempio di struttura poetica medievale: le cantigas de amigo di Martim Codax". in Arquivos do Centro Cultural Português, vol. XV. Paris: Fundação C. Gulbenkian, 1980, pp. 749-839.

TAFALL ABAD, Santiago - “Texto musical de Martín Codax (interpretación y crítica)”. Boletín de la Real Academia Gallega, XII/118 (1917), pp. 265-71.

TAVANI, Giuseppe - Poesia e Ritmo. Lisboa: Sá da Costa, 1983.

TAVANI, Giuseppe - A poesia lírica galego-portuguesa. Lisboa: Editorial Comunicação, 1988.

UREÑA, Pedro Henríquez - La versificación irregular en la poesía castellana, $2^{\mathrm{a}}$ ed. Madrid: Centro de Estudos Históricos, 1933.

\section{NOTAS}

1. Versão revista da conferência apresentada a 10 de Janeiro de 2018 no âmbito do Doutoramento em Estudos Medievais na NOVA FCSH, baseada em comunicações lidas no XVII Congresso Internacional da Associação Hispânica de Literatura Medieval (Roma, Setembro de 2017) e no Simpósio Internacional “E irei madr’a Vigo” (Vigo, Novembro de 2017).

2. FERREIRA, Manuel Pedro - O som de Martin Codax - Sobre a dimensão musical da lírica galegoportuguesa (séculos XII-XIV). Lisboa: Imprensa Nacional - Casa da Moeda, 1986. HILLIER, Paul; The Theatre of Voices - Cantigas from the Court of Dom Dinis (CD HMU 907129). Los Angeles: Harmonia Mundi USA, 1995. FERREIRA, Manuel Pedro - Cantus Coronatus - Sete cantigas d'El-Rei Dom Dinis. Kassel: Reichenberger, 2005.

3. PADEN, William D. - "Principles of Generic Classification in the Medieval European Lyric: The Case of Galician-Portuguese". Speculum 81/1 (2006), pp. 76-96.

4. TAVANI, Giuseppe - A poesia lírica galego-portuguesa. Lisboa: Editorial Comunicação, 1988, p. 144: "Na maior parte dos casos, a cantiga d'amigo apresenta-se como o reverso exacto da cantiga d'amor: seja porque os conceitos aqui expressos pelo poeta na primeira pessoa são os mesmos que, na outra, são atribuídos à mulher, seja porque esta responde, de uma maneira ou de outra, aos lamentos e às solicitações do amante".

5. MIRANDA, José Carlos Ribeiro - "Calheiros, Sandim e Bonaval: uma rapsódia de amigo". Guarecer - revista electrónica de estudos medievais 1 (2016), pp. 47-62 [texto inicialmente publicado em 1994 em edição de autor]. MIRANDA, José Carlos Ribeiro - "Le surgissement de la culture troubadouresque dans l'occident de la Péninsule Ibérique: Les genres, les thèmes et les formes". in TOUBER, Anton (Ed.) - Le rayonnement des troubadours. Actes du colloque de l'Association Internationale d'Études Occitanes. Amsterdam: Rodopi, 1998, pp. 97-105. OLIVEIRA, António Resende de - "Para uma integração histórico-cultural do canto trovadoresco galego-português". Máthesis 8 (1999), pp. 125-45. Visão oposta tem DEYERMOND, Alan - "Some Problems of Gender and Genre in the Medieval Cantigas". in OCAÑA, Antonio Cortijo; PERISSINOTTO, Giorgio; SHARRER, Harvey L. 
(Eds.) - Estudios galegos medievais. Santa Barbara: Centro de Estudios Galegos, Department of Spanish and Portuguese, University of California at Santa Barbara [Studia Hispanica Californiana, 1], 2001, pp. 43-59.

6. PADEN, William D. - "The chronology of genres in medieval Galician-Portuguese lyric poetry". La corónica 26/1 (1997), pp. 183-201. Há comentário crítico em DEYERMOND, Alan - "Some Problems of Gender and Genre", pp. 53-54, 56n.

7. "Se assim é, a música da última geração de trovadores não deveria equivaler à da primeira, e nem a melodia de uma cantiga de amigo mais primitiva teria os mesmos artifícios de uma cantiga de amor 'à moda provençal' ", conclui MONGELLI, Lênia Márcia - "Fremosos cantos: reflexões metodológicas sobre a lírica galego-portuguesa". Bulletin du centre d'études médiévales d'Auxerre I BUCEMA [En ligne], Hors-série $n^{\circ} 2$ (2008). Ligação: http://cem.revues.org/9112 [\#18] [acedido a 17 de Outubro de 2017].

8. PADEN, William D. - "On the Music of Galician-Portuguese Secular Lyric: Sources, Genres, Performance”. in D'EMILIO, James (Ed.) - Culture and Society in Medieval Galicia: A Cultural Crossroads at the Edge of Europe. Leiden: Brill, 2015, pp. 862-893.

9. HENRÍQUEZ UREÑA, Pedro - La versificación irregular en la poesía castellana, $2^{\mathrm{a}}$ ed. Madrid: Revista de filología española, 1933. DUARTE, Luiz Fagundes - "Acerca do Ritmo nas Cantigas de Amigo". in Actes du XVII Congrès International de Linguistique et Philologie Romanes. Aix-en-Provence: Université de Provence, 1986, vol. 8, pp. 225-236. PRIETO ALONSO, Domingos - "A métrica acentual na cantiga de amigo". in Estudos Portugueses: Homenagem a Luciana Stegagno Picchio. Lisboa: Difel, 1991, pp. 111-142. DUfFELL, Martin J. - “The Metric Cleansing of Hispanic Verse”. Bulletin of Hispanic Studies 76 (1999), pp. 151-168 [159-160]. PARKINSON, Stephen - "Concurrent Patterns of Verse Design in the Galician-Portuguese Lyric". in WHETNALL, J.; DEYERMOND, A. (Eds.) - Proceedings of the Thirteenth Colloquium [PMHRS, 51]. London: Department of Hispanic Studies, Queen Mary, University of London, 2006, pp. 19-38.

10. FERREIRA, Manuel Pedro - "Codax revisitado". Anuario de estudos literarios galegos (1998), pp. 157-168. FERREIRA, Manuel Pedro - "Musik und Betonung in cantigas d'amigo". in CRAMER, Thomas et alii (Eds.) - Frauenlieder - Cantigas de amigo. Stuttgart: S. Hirzel, 2000, pp. 247-257; FERREIRA, Manuel Pedro - "Estrutura e ornamentação melódica nas cantigas trovadorescas". in Aspectos da Música Medieval no Ocidente Peninsular, vol. 1: Música palaciana, Lisboa, Imprensa Nacional - Casa da Moeda / Fundação Calouste Gulbenkian, 2009, pp. 150-74. Neste volume apresentam-se também, em português, os textos anteriores. Conceda-se contudo, que à luz do recente artigo de Massini-Cagliari sobre a combinação do texto e da música nas cantigas do Pergaminho Sharrer (no qual a autora aplicou a minha definição de apoio acústico, proposta em 1986, para testar a sua coordenação com a tonicidade silábica), a polaridade estética entre a cantiga paralelística e a cantiga d'amor poderá ser menos vincada do que dei a entender, pois, segundo a sua análise (que não tentei replicar), verifica-se a tendência, em ambos os casos, para a acentuação musical coincidir com a lexical: MASSINI-CAGLIARI, Gladis - "A notação musical como fonte para o estudo do ritmo lingüístico no período trovadoresco do português: as cantigas de amor de D. Dinis". in MASSINI-CAGLIARI, Gladis; MUNIZ, Márcio R. C.; SODRÉ, Paulo Roberto (Orgs.) - Série Estudos Medievais 2: Fontes [recurso electrónico]. Vol. I. Araraquara: Associação Nacional de Pós-Graduação e Pesquisa em Letras e Lingüística, 2009, pp. 63-79.

11. DEYERMOND, Alan - "Some Problems of Gender and Genre", p. 52. Tradução do autor.

12. DEYERMOND, Alan - "Some Problems of Gender and Genre", pp. 46-47. Minha tradução. A argumentação do autor a favor de um substracto tradicional feminino na cantiga d'amigo paralelística continua nos parágrafos seguintes. Os trabalhos citados no excerto traduzido são: MONROE, James T. - "Formulaic Diction and the Common Origins of Romance Lyric Tradition". Hispanic Review 43 (1975), pp. 341-50. SCHAFFER, Martha E. - "The Galician-Portuguese Tradition and the Romance Kharjas". Portuguese Studies 3 (1987), pp. 1-20. Argumentos adicionais a favor do tradicionalismo da cantiga d'amigo podem ser colhidos em COHEN, Rip - "In the Beginning was 
the Strophe: Origins of the Cantiga d'Amigo Revealed!". in LARANJINHA, Ana Sofia; MIRANDA, José Carlos (Coords.). Modelo: Actas do X Colóquio da Secção Portuguesa da Associação Hispânica de Literatura Medieval. Porto: Faculdade de Letras da Universidade do Porto, 2005, pp. 243-255; COHEN, Rip - "Internal rhyme and the history of strophic song". Washington DC: Virtual Center for the Study of Galician-Portuguese Lyric, 2014. https://blogs.commons.georgetown.edu/ cantigas (Acedido a 28/04/2015).

13. Considerando que Codax seria uma alcunha eventualmente omitível, aventei recentemente a hipótese de se poder tratar do Martim jograr, clericus que estava em 1254 ao serviço do arcebispo de Compostela Xoán Arias (1238-1266), o qual tinha desde 1236 jurisdição civil sobre Vigo, e teria assim interesse em publicitar a vila: FERREIRA, Manuel Pedro - "Ler o Pergaminho Vindel: suporte; textos; autor". in LOPES, Graça Videira; FERREIRA, Manuel Pedro (Coords.) - Do canto à escrita: novas questões em torno da lírica galego-portuguesa. Lisboa: IEM/ CESEM, 2016, pp. 19-28 [27-28]. No decurso do Simpósio "E irei madr'a Vigo", sugeriu-se que o uso do verbo mirar por Martin Codax apontaria para uma origem no sudoeste da Galiza, o que não contradiz a hipótese anterior. Sobre as particularidades lingüísticas do Pergaminho Vindel, veja-se MONTEAGUDO, Henrique, et alii - Tres poetas medievais da Ría de Vigo: Martín Codax, Mendiño e Xohán de Cangas. Vigo: Editorial Galaxia, 1998, pp. 155-158.

14. TAFALL ABAD, Santiago - "Texto musical de Martín Codax (interpretación y crítica)". Boletín de la Real Academia Gallega, XII/118 (1917), pp. 265-271. Para as características do alalá, veja-se SAMPEDRO Y FOLGAR, Casto - Cancionero Musical de Galicia. A Coruña: Fundación "Pedro Barrié de la Maza, Conde de Fenosa”, 1982 (1942); SCHUBARTH, Dorothé; SANTAMARINA, Antón Cancioneiro Galego de tradición oral. A Coruña: Fundación "Pedro Barrié de la Maza, Conde de Fenosa”, 1982; SCHUBARTH, Dorothé; SANTAMARINA, Antón - Cancioneiro Popular Galego, 3 vols. A Coruña: Fundación “Pedro Barrié de la Maza, Conde de Fenosa”, 1984-1987.

15. ANGLÉS, Higinio - La Música de las Cantigas de Santa María del Rey Alfonso El Sabio, vol. III/2. Barcelona: Diputación Provincial de Barcelona - Biblioteca Central, 1958, p. 451. Minha tradução. 16. LÓPEZ-CALO, José - La música medieval en Galicia. La Coruña: Fundación "Pedro Barrié de la Maza, conde de Fenosa", 1982, p. 74. Minha tradução. Esta posição foi reafirmada mais tarde pelo autor: LÓPEZ-CALO, José - “O feito diferencial galego na música. Idade Media e Renacemento". in o feito diferencial galego na música. Vol. II. Santiago de Compostela: A Editorial da Historia /Museo do Pobo Galego, 1998, pp. 9-39 [21-22].

17. RIBERA, Julián - “De música y métrica gallegas”. in Homenage a Menéndez Pidal. Madrid, 1925, vol. III, pp. 7-35 [30-34]; MARTÍNEZ TORNER, Eduardo (selección y armonización) - Cancionero musical. Madrid, 1928, pp. vi-vii, 1-6.

18. POPE, Isabel - "Medieval Latin Background of the Thirteenth-Century Galician Lyric". Speculum 9 (1934), pp. 3-25; RIBEIRO, Mário de Sampayo - “À margem do Cancioneiro de Manuel Joaquim”. Brotéria 33 (1941), pp. 383-417 [407]; ALEGRIA, José Augusto - A problemática musical das cantigas de amigo. Lisboa: Fundação Calouste Gulbenkian, 1968, pp. 11-12.

19. BREWER, Charles E. - "The Cantigas d'Amigo of Martin Codax in the Context of Medieval Secular Latin Song”. La corónica 26/2 (1998), pp. 17-28.

20. PADEN, William D. - "On the Music of Galician-Portuguese Secular Lyric".

21. Salvo indicação em contrário, os exemplos e os dados sintetizados nos respectivos comentários são retirados de FERREIRA, Manuel Pedro - 0 som de Martin Codax.

22. A nova transcrição apresentada baseia-se em FERREIRA, Manuel Pedro - 0 som de Martin Codax , p. 133, com a modificação proposta em FERREIRA, Manuel Pedro - "Codax revisitado" (cito pela versão portuguesa: FERREIRA, Manuel Pedro - Aspectos da Música Medieval no Ocidente Peninsular, vol. 1: Música palaciana. Lisboa: Imprensa Nacional - Casa da Moeda / Fundação Calouste Gulbenkian, 2009, pp. 88-100 [94]).

23. FERREIRA, Manuel Pedro - "Jograis, contrafacta, formas musicais: cultura urbana nas Cantigas de Santa Maria”. Alcanate. Revista de Estudios Alfonsíes 8 (2012-2013), pp. 43-53. 
24. O tom salmódico é aqui exemplificado segundo um tratado datado de 1271, presumivelmente contemporâneo de Codax: AMERUS - Practica artis musice. Ed. Cesarino Ruini. Corpus scriptorum de musica, vol. 25. [Roma]: American Institute of Musicology, 1977, p. 39. A transcrição da cantiga retoma aquela publicada in FERREIRA, Manuel Pedro (dir.) - Antologia de Música em Portugal na Idade Média e no Renascimento. Vol II. 2 vols., 2 CDs. Lisboa: Arte das Musas / CESEM, 2008, p. 27.

25. Transcrições originalmente publicadas in FERREIRA, Manuel Pedro - 0 som de Martin Codax, p. 135, e FERREIRA, Manuel Pedro - Cantus Coronatus, pp. 132-133; esta última reproduzida a partir da versão compacta (sem replicação da notação original a encimar as pautas) incluída in LOPES, Graça Videira (Ed.) - Cantigas medievais galego-portuguesas: corpus integral profano. Vol. II. 2 vols. Lisboa: Biblioteca Nacional de Portugal / IEM / CESEM, 2016, Anexo V, p. 600.

26. HUSEBY, Gerardo Victor - "The common melodic background of 'Ondas do mar de Vigo' and CSM \#73". in Studies on the Cantigas de Santa Maria: Art, Music, and Poetry. Madison, Wis.: Hispanic Seminary of Medieval Studies, 1987, pp. 189-201. Este texto data de 1981; foi citado, antes da sua publicação, in FERNÁNDEZ DE LA CUESTA, Ismael - Historia de la música española, 1. Desde los orígenes hasta el "ars nova". Madrid: Alianza Editorial, 1983, p. 293 e FERREIRA, Manuel Pedro - O som de Martin Codax, pp. 101, 117.

27. FERNÁNDEZ DE LA CUESTA, Ismael - "Les cantigas de amigo de Martín Codax". Cahiers de civilisation médiévale 25 (1982), pp. 179-185 e 4 lâminas.

28. FERNÁNDEZ DE LA CUESTA, Ismael - Historia de la música española, p. 293. Tradução do autor.

29. FERREIRA, Manuel Pedro - $O$ som de Martin Codax.

30. CALVIA, Antonio - "A música do Pergamiño Vindel”. in Pergamino Vindel. Barcelona: M. Moleiro, 2016, pp. 161-82. Não tive acesso ao trabalho, aí citado, de MONARI, Giorgio - Le cantigas de amigo di Martin Codax e l'interpretazione del ritmo della monodia medievale. Roma: Nuova cultura, 2004.

31. FERREIRA, Manuel Pedro - O som de Martin Codax, pp. 39-47.

32. FERREIRA, Manuel Pedro - "Estrutura e ornamentação melódica”, pp. 167-168, 174.

33. PARKINSON, Stephen - "Métrica acentual nas cantigas de amigo". in LOPES, Graça Videira; FERREIRA, Manuel Pedro (Coords.) - Do canto à escrita: novas questões em torno da lírica galegoportuguesa. Lisboa: IEM/ CESEM, 2016, pp. 29-42. Na coluna da direita, há na publicação original algumas gralhas, aqui corrigidas. Esta cantiga foi analisada com algum detalhe em PARKINSON, Stephen - "Concurrent Patterns", pp. 29-30.

34. COHEN, Rip - 500 Cantigas d'Amigo. Edição crítica. Porto: Campo das Letras, 2003.

35. COHEN, Rip - "The Cantigas of Martin Codax - Edited with Commentary and Prolegomena". in Pergamino Vindel. Barcelona: M. Moleiro, 2016, pp. 285-305.

36. CUNHA, Celso Ferreira da - "Sobre o texto e a interpretação das cantigas de Martin Codax". in Critique textuelle portugaise. Actes $d u$ coloque (Paris, 20-24 octobre 1981). Paris: Centre Culturel Portugais, 1986, pp. 65-83 (reimpressão: Cancioneiros dos trovadores do mar. Lisboa: Imprensa Nacional - Casa da Moeda, 1999, pp. 511-529). Face à imprevisibilidade do Pergaminho Vindel, Cohen adopta uma ordenação canónica das estrofes, a qual provavelmente traduz o critério editorial dos transcritores quinhentistas, como é reconhecido, entre outros, por Stephen Reckert (RECKERT, Stephen; MACEDO, Hélder - Do cancioneiro de amigo, $3^{a}$ edição. Lisboa: Assírio \& Alvim, 1996, pp. 166-167) e Henrique Monteagudo (MONTEAGUDO, Henrique et alii - Tres poetas medievais da Ría de Vigo, p. 110).

37. SPAGGIARI, Barbara - "Il canzoniere di Martim Codax". Studi medievali, 3a. serie, 21/1 (1980), pp. 367-409.

38. RECKERT, Stephen; MACEDO, Hélder - Do cancioneiro de amigo, $1^{\mathrm{a}}$ edição. Lisboa: Assírio \& Alvim, 1976. FERNÁNDEZ GUIADANES, Antonio et alii - Cantigas do Mar de Vigo. Edición crítica das cantigas de Meendinho, Johan de Cangas e Martin Codax. Santiago de Compostela: Centro Ramón Piñeiro, 1998. 
39. CUNHA, Celso Ferreira da - O Cancioneiro de Martin Codax. Rio de Janeiro, 1956 (reimpressão: Cancioneiros dos trovadores do mar. Lisboa: Imprensa Nacional - Casa da Moeda, 1999), p. 56; FERNÁNDEZ GUIADANES, Antonio et alii - Cantigas do Mar de Vigo, pp. 197-208.

40. NUNES, José Joaquim - Cantigas d'Amigo dos trovadores galego-portugueses. Vol. III. 3 vols. Coimbra, 1926-1928, p. 420, citado por CUNHA, Celso Ferreira da - O Cancioneiro de Martin Codax, p. 55. SPAGGIARI, Barbara - "Il canzoniere di Martim Codax", p. 378; SPAGGIARI, Barbara - "Un esempio di struttura poetica medievale: le cantigas de amigo di Martim Codax". in Arquivos do Centro Cultural Português, vol. XV, Paris: Fundação C. Gulbenkian, 1980, pp. 749-839 [798]. DUARTE, Luiz Fagundes - "Acerca do Ritmo nas Cantigas de Amigo". PRIETO ALONSO, Domingos - "A métrica acentual na cantiga de amigo", pp. 135-140 (contrariamente ao declarado, o autor baseia a sua análise na edição da cantiga por José Joaquim Nunes). COHEN, Rip - "The Cantigas of Martin Codax". Esta última edição, que me suscita fortes reservas, é consideravelmente diferente daquela apresentada em COHEN, Rip - 500 Cantigas d'Amigo, p. 515.

41. PARKINSON, Stephen - "Concurrent Patterns"; PARKINSON, Stephen - "Métrica acentual"; e comunicação pessoal. Recorde-se que em TAVANI, Giuseppe - Poesia e Ritmo. Lisboa: Sá da Costa, 1983, pp. 145-146 e 154, após delimitação das possibilidades de acentuação através do controle a nível sintagmático, os acentos que contam são só dois acentos fortes em cada verso. A sua teoria foi rebatida em FERREIRA, Manuel Pedro - O som de Martin Codax, p. 175.

42. Chamámos a atenção para estas possibilidades no capítulo "Música e acentuação nas cantigas d'amigo", in FERREIRA, Manuel Pedro - Aspectos da Música Medieval, I, pp. 101-112 [107-108].

43. Basta aceitar a contagem tradicional de treides como dissílabo, respeitar a distinção observada no manuscrito entre Vigo u (verso 4) e Vig'u (verso 7) - sendo o verso 2 lacunoso e o 5, Vigou, inconclusivo - e desdobrar madré em madre e. Para a justificação destas últimas decisões, veja-se FERREIRA, Manuel Pedro - 0 som de Martin Codax, pp. 147-149. A distinção (gráfica) entre Vigo u e Vig'u foi adoptada em FERNÁNDEZ GUIADANES, Antonio, et alii - Cantigas do Mar de Vigo, p. 197.

44. FERREIRA, Manuel Pedro - O som de Martin Codax, pp. 171-175.

45. FERREIRA, Manuel Pedro - O som de Martin Codax, pp. 55-57.

46. FERREIRA, Manuel Pedro - "Editing the Cantigas de Santa Maria: Notational decisions". Revista Portuguesa de Musicologia, nova série, 1/1 (2014), pp. 33-52.

47. FERREIRA, Manuel Pedro - "Estrutura e ornamentação melódica", pp. 170-174.

48. MULLALLY, Robert - The Carole: A Study of a Medieval Dance. Farnham and Burlington, Vt.: Ashgate, 2011. Para o contexto feminino da carole, veja-se também BOYNTON, Susan - "Women's Performance of the Lyric Before 1500". in KLINCK, Anne; RASMUSSEN, Ann Marie (Eds.) Medieval Woman's Song: Cross-Cultural Approaches. Philadelphia: University of Pennsylvania Press, 2002, pp. 47-65. Segundo Deyermond, o paralelismo com refrão ajusta-se tão bem à estrutura das danças de roda que é improvável que se trate de fenómenos sem relação entre si (DEYERMOND, Alan - "Some Problems of Gender and Genre", p. 47).

49. Cf. Dom Dinis, "Quer'eu em maneira de proençal", cantiga d'amor publicada com a melodia do modelo seguido (uma canção de Peire Vidal) in LOPES, Graça Videira (ed. coord.) - Cantigas medievais galego-portuguesas, vol. 2, pp. 603-605. 


\section{RESUMOS}

O cancioneiro de Martin Codax tem suscitado posições interpretativas nem sempre conciliáveis entre si. Aqui são apresentadas e discutidas as contribuições recentes mais significativas, em particular as de William Paden. Passa-se seguidamente a tentar perceber que aspectos musicais, no Pergaminho Vindel, poderão apontar para um antigo estilo de canção feminina simbolizado pela temática de "amigo". Convocam-se os estudos de género e o seu impacto no debate sobre a cantiga d'amigo, avaliado por Alan Deyermond; apresentam-se as diversas abordagens suscitadas pelas melodias desde que foram descobertas. Explora-se ainda a diferença entre as cantigas II e III e as restantes aí apontadas, bem como a interpretação métrica da terceira, com referência aos trabalhos recentes de Stephen Parkinson e Rip Cohen, propondo-se novas edições musicais para essas duas cantigas (e também, de passagem, para a cantiga V). São finalmente identificados, de forma hipotética, os aspectos estilísticos no Pergaminho que poderão remontar à esfera da canção de mulher, por oposição aos que provavelmente espelham uma elaboração artística de iniciativa dos jograis galegos.

The songs by Martin Codax have been interpreted according to different, often incompatible, perspectives. The author discusses the most recent and relevant contributions, namely by William Paden. Then he tries to ascertain which musical traits in these cantigas might point to an earlier style of women's song symbolized by the "boyfriend" and related keywords. After invoking the impact of gender studies on the interpretation of the cantiga de amigo, as evaluated by Alan Deyermond, the author presents and discusses the different views on the style of the melodies voiced since their discovery a century ago. An excursus explores differences between cantigas II and III and the remaining, and the metrics of the latter, with reference to a recent work by Stephen Parkinson and Rip Cohen; a new musical edition is proposed for these two (and also, in passing, for cantiga V). Finally, those stylistic aspects that in the Vindel MS may betray an earlier tradition, in contrast to those that can be attributed to the artistic initiative of Galician jongleurs, are tentatively identified.

\section{ÍNDICE}

Keywords: Cantiga d'amigo, Gender, Music, Metrics, Accentuation

Palavras-chave: Cantiga d'amigo, Género, Música, Métrica, Acentuação

\section{AUTOR}

\section{MANUEL PEDRO FERREIRA}

Universidade Nova de Lisboa, Centro de Estudos de Sociologia e Estética Musical, Faculdade de Ciências Sociais e Humanas da Universidade Nova de Lisboa, 1069-061, Lisboa, Portugal mpferreira@fcsh.unl.pt 